\title{
Oxidation Resistance and Modification Reaction Mechanism of Al Coating Sprayed on Pure Ti Substrate
}

\author{
Qianqian Jia, ${ }^{1,2}$ Deyuan Li, ${ }^{1}$ Sheng Guan, ${ }^{3}$ Zhuang Zhang, ${ }^{1}$ Nannan Zhang ${ }^{D},{ }^{1}$ \\ and Wenzhen Zhao ${ }^{4}$ \\ ${ }^{1}$ Department of Material Science and Engineering, Shenyang University of Technology, Shenyang 110870, China \\ ${ }^{2}$ Guidao Jiaotong Polytechnic Institute, Shenyang 110023, China \\ ${ }^{3}$ Dalian Huarui Heavy Industrial Special Spare Parts Co., Ltd., Dalian 116052, China \\ ${ }^{4}$ School of Mechanical Engineer, Shenyang University of Technology, Shenyang 110870, China
}

Correspondence should be addressed to Nannan Zhang; zhangnn@sut.edu.cn

Received 27 July 2018; Revised 5 September 2018; Accepted 12 September 2018; Published 15 October 2018

Academic Editor: Shuo Yin

Copyright ( 92018 Qianqian Jia et al. This is an open access article distributed under the Creative Commons Attribution License, which permits unrestricted use, distribution, and reproduction in any medium, provided the original work is properly cited.

\begin{abstract}
$\mathrm{An} \mathrm{Al}$ coating was deposited on the surface of pure Ti substrate by arc spray technology. In order to enable the modification reaction between the $\mathrm{Al}$ coating and $\mathrm{Ti}$ substrate, the specimen was heated to a temperature above the melting point of $\mathrm{Al}$. Oxidation testing of the uncoated $\mathrm{Ti}$ and coated specimen was conducted at $1073 \mathrm{~K}$ under an air atmosphere. The microstructure, chemical composition, and phase determination of the coatings and interfaces, before and after modification treatment, were done using SEM, EDS, and XRD methods. The relationships between the modification results and time and temperature were discussed. The results showed that, after heating at $973 \mathrm{~K}$ for 5 hours, there was still sufficient $\mathrm{Al}$ on the surface of the specimen. Only intermetallic $\mathrm{TiAl}_{3}$ was formed in the diffusion region. After heating at $1073 \mathrm{~K}$ for 5 hours, all the $\mathrm{Al}$ elements diffused into the Ti substrate. Intermetallics $\mathrm{TiAl}_{2}$ and $\mathrm{Ti}_{3} \mathrm{Al}$ were also formed in the diffusion front of $\mathrm{Al}$, in addition to $\mathrm{TiAl}_{3}$. After heating at $1173 \mathrm{~K}$ for 5 hours, a new intermetallic TiAl phase was formed at the interface of $\mathrm{TiAl}_{2}$ and $\mathrm{Ti}_{3} \mathrm{Al}$. As the modification reaction time was prolonged at $1173 \mathrm{~K}$, the formation of intermetallics $\mathrm{TiAl}_{2}, \mathrm{TiAl}$, and $\mathrm{Ti}_{3} \mathrm{Al}$ were all increased. Among them, the formation amount of $\mathrm{TiAl}_{2}>\mathrm{Ti}_{3} \mathrm{Al}>\mathrm{TiAl}$. The specimen after modification treatment had better high temperature oxidation resistance than the pure Ti substrate without coating.
\end{abstract}

\section{Introduction}

Titanium and titanium alloys are widely used in the fields of aerospace, chemical production, and the like, due to their high specific strength, low density, and the superior corrosion resistance [1-5]. However, when the temperature is higher than $873 \mathrm{~K}$, the life of the materials is seriously affected due to several factors [4]. These include a decrease in the strength and decay of other mechanical properties, such as plasticity. After adding a coating that has excellent oxidation resistance to the surface of $\mathrm{Ti}$ alloys, the oxidation resistance was significantly improved while it maintained outstanding performance [6].

$\mathrm{Al}$ always has excellent oxidation resistance since a dense, stable $\mathrm{Al}_{2} \mathrm{O}_{3}$ film can be formed on the surface of metal materials [7]. Ti-Al intermetallics are often used as the materials for heat-resistant coatings on titanium and titanium alloys due to the capability of forming Al-rich oxide scales of TiAl [8]. At present, different methods have been used by many researchers to fabricate $\mathrm{Ti}-\mathrm{Al}$ intermetallic coatings on alloys directly or by modification treatment, such as mechanical alloying [9], laser cladding [10], tungsten inert gas welding surfacing [11], laser surface alloying [12], high-vacuum arc ion plating [8], and high-energy ball milling that combines heat treatment [13], and a solid phase diffusion reaction [14]. However, the fabrication of an $\mathrm{Al}$ coating on the surface of pure Ti substrate by arc spray technology, and then heating the specimen to a temperature above the melting point of $\mathrm{Al}$ in order to form a TiAl intermetallic, has seldom been reported [15]. 
In this paper, an $\mathrm{Al}$ coating was fabricated on the surface of a pure Ti substrate by arc spray technology. In order to enable the reaction between the $\mathrm{Al}$ coating and $\mathrm{Ti}$ substrate, the specimen was heated at different temperatures (above the melting point of $\mathrm{Al}$ ) and times, and the impact of the modification temperature and time was determined. Oxidation testing of the specimen after modification treatment and a pure $\mathrm{Ti}$ control was conducted at $1073 \mathrm{~K}$. The effect of the coating on the oxidation resistance, and its protection mechanism, were investigated. The results may provide some theoretical basis for the production of Ti-Al intermetallic coating by the method of modification reaction between coating and substrate at higher temperature.

\section{Experimental Procedure}

The substrate material used in this study was industrial pure Ti. All of the substrate specimens were formed into a $30 \mathrm{~mm}$ long, $30 \mathrm{~mm}$ wide, and $10 \mathrm{~mm}$ thick shape. Prior to spraying the coatings, ethanol and acetone were used to remove oil on the surfaces of substrates, and then the substrate surfaces were grit blasted with granular corundum to obtain a roughened surface. All of the surfaces of the specimens were sprayed with $0.5 \mathrm{~mm}$ thick $\mathrm{Al}$ coatings by arc spray technology, and then the specimens in different ceramic boats were treated by heating as follows under an air atmosphere in the resistance furnace: $973 \mathrm{~K} / 5 \mathrm{~h}, 1073 \mathrm{~K} / 5 \mathrm{~h}, 1173 \mathrm{~K} / 5 \mathrm{~h}, 1173 \mathrm{~K} / 10 \mathrm{~h}$, and $1173 \mathrm{~K} / 20 \mathrm{~h}$ (better results might be obtained if the heat treatment of the specimens were performed under vacuum or protection gas atmosphere. But in consideration of the practical application, the large titanium plate would be difficult to be performed heat treatment under vacuum or protection gas atmosphere). The spraying material was industrial Al welding wire (2 $\mathrm{mm}$ in diameter) which had a purity of greater than $99.8 \%$. The arc spray equipment was type XDP-5, which was homemade by Shenyang University of Technology. The parameters for the arc spray process are listed in Table 1.

The microstructures of the coatings before and after modification treatment were characterized by a scanning electron microscope (SEM; S-3400 and S-4800, Hitachi, Japan). The distribution of chemical elements at the coating-interface-substrate regions was characterized by EDS. The intermetallic compounds formed in the diffusion reaction process were characterized by X-ray diffraction (XRD; Shimadzu, 7000, Kyoto, Japan) with $\mathrm{Cu}-\mathrm{Ka}$ radiation $(\lambda=0.1541 \mathrm{~nm})$ at $40 \mathrm{KV} 30 \mathrm{~mA}$. Since the thickness of most $\mathrm{Ti}-\mathrm{Al}$ intermetallic layers which were formed during the modification reaction was too thin, it was difficult to polish to reveal the surfaces of different layers. So in this experiment, not all the layers were identified with $\mathrm{XRD}$, the chemical composition of most diffusion reaction regions was characterized by energy-dispersive spectrometer $(\mathrm{EDS})\left(V_{\mathrm{a} / \mathrm{c}}=20.0 \mathrm{KV}\right)$, which was equipped with SEM.

The $\mathrm{Al}_{2} \mathrm{O}_{3}$ film on the specimen was removed by the waterproof abrasive paper (500\#) after modification
TABLe 1: Arc-sprayed parameters.

\begin{tabular}{lcccc}
\hline Materials & $\begin{array}{c}\text { Voltage } \\
(\mathrm{V})\end{array}$ & $\begin{array}{c}\text { Current } \\
(\mathrm{A})\end{array}$ & $\begin{array}{c}\text { Atomization } \\
\text { compressed air supply } \\
\text { pressure }(\mathrm{MPa})\end{array}$ & $\begin{array}{c}\text { Distance } \\
(\mathrm{mm})\end{array}$ \\
\hline $\mathrm{Al}$ & 31 & 180 & 0.6 & 150 \\
\hline
\end{tabular}

treatment. It was then put in a ceramic boat, which was dried to constant weight. Oxidation resistance of the specimen after treatment was performed at $1073 \mathrm{~K}$ for 100 hours under an air atmosphere in the furnace. Every 10 hours, the specimen was removed from the furnace, and then it was cooled to room temperature in the atmosphere; the heating rate of the furnace was $293 \mathrm{~K} / \mathrm{min}$, and the air cooling rate was about $298 \mathrm{~K} / \mathrm{min}$. The comparative experiments for the pure Ti control were performed under similar conditions. The mass gain of the specimen was weighed during every period on an electronic balance, which was accurate to $0.1 \mathrm{mg}$. The oxidation kinetics curves of the specimen and the pure Ti were then obtained.

\section{Results and Discussion}

Figure 1 shows the microstructure of the interface that was not heated. As shown in Figure 1, the dark gray area is the Al coating, which was about $500 \mu \mathrm{m}$ thick, and the region under the $\mathrm{Al}$ coating is the Ti substrate. There were some black pores in the coating. This occurred because after the $\mathrm{Al}$ particles in a molten state were sprayed on the surface of the substrate, the surface temperature of the particles decreased rapidly and lead to the large temperature difference between the surface and inside of the particles. As a result, Al particles were present as spheres and pores appeared. The porosity of the thermal spraying coating was about $3 \%-5 \%$. In addition, the bonding between the $\mathrm{Al}$ coating and Ti substrate was mechanical. It was not very compact, and there were also some pores at the interface between the $\mathrm{Al}$ coating and the substrate.

Figure 2 shows the cross-sectional BSD image of the $\mathrm{Al}$ coating after testing for 5 hours at $973 \mathrm{~K}$ (Figure 2(a)) and the distributions of $\mathrm{Al}$ (Figure 2(b)) and Ti (Figure 2(c)). As shown in Figure 2, after heating at $973 \mathrm{~K}$ for 5 hours, there was still surplus $\mathrm{Al}$ on the surface of the specimen, and some of the Al diffused into the Ti substrate.

As shown in Figure 3, after heating at $973 \mathrm{~K}$ for 5 hours, a $0.5 \mathrm{~mm}$ thick light gray diffusion region was formed between the Al coating and the Ti substrate. The pores between the $\mathrm{Al}$ coating and the $\mathrm{Ti}$ substrate, which are shown in Figure 1, disappeared as the modification reaction proceeded. Figure $3(\mathrm{~b})$ is the expanded view of region $I$ in Figure 3(a), and it can be seen from Figures 3(a) and 3(b) that a new phase with a continuous distribution was formed in the diffusion region. The chemical composition (at.\%) at points A, B, C, and D, as marked in Figure 3(b), is listed in Table 2.

It can be determined that the phases of points $\mathrm{A}, \mathrm{B}, \mathrm{C}$, $\mathrm{D}$, and $\mathrm{E}$ were intermetallic $\mathrm{TiAl}_{3}$ upon comparing their chemical compositions with the theoretical ratio ranges of intermetallic $\mathrm{TiAl}_{3}$. The white-gray region which was 


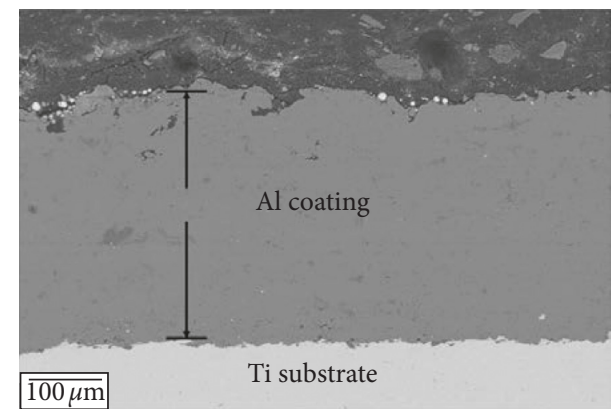

FIGURE 1: Cross-sectional BSD image of Al coating without heating.

represented by $\mathrm{F}$ point was $\mathrm{Ti}$ substrate. Since $\mathrm{Al}$ in the diffusion zone closed to the substrate-diffusion zone interface is not homogenous, that part was represented by $\mathrm{A}$, $\mathrm{C}$, and $\mathrm{D}$ points which looks like darker.

After heating at $973 \mathrm{~K}$ for 5 hours, Al coating $(400-500 \mu \mathrm{m})$ was still on the surface of the specimen. A $500 \mu \mathrm{m}$ thick surface layer was then removed in order to expose the diffusion region completely. The XRD results are shown in Figure 4. This data indicate that the diffusion region between the $\mathrm{Al}$ coating and the Ti substrate consisted of the $\mathrm{TiAl}_{3}$ phase. This is the intermetallic structure that formed during the modification reaction between $\mathrm{Al}$ and $\mathrm{Ti}$. Since XRD can detect phases that are typically above $2-5 \%$, some Al might be also present on the surface of the specimen.

Figure 5 shows the cross-sectional BSD image of the Al coating after testing for 5 hours at $1073 \mathrm{~K}$ (Figure 5(a)) and the distributions of $\mathrm{Al}$ (Figure 5(b)) and Ti (Figure 5(c)). As shown in Figure 5, after heating at $1073 \mathrm{~K}$ for 5 hours, the $\mathrm{Al}$ coating disappeared and all of the $\mathrm{Al}$ elements diffused into the Ti substrate.

As shown in Figure 6, after the modification reaction at $1073 \mathrm{~K}$ for 5 hours, all of the $\mathrm{Al}$ diffused into the $\mathrm{Ti}$ substrate and a $0.9 \mathrm{~mm}$ thick diffusion region was formed. Compared with the thickness of the diffusion region which was formed at $973 \mathrm{~K}$, the thickness increased at 1073 K. As can be seen in Figure 6, a region with different shades appeared in the diffusion region near the $\mathrm{Ti}$ substrate. This showed that different kinds of intermetallic compounds were formed in the diffusion front of $\mathrm{Al}$. Figures 6(c) and 6(d) show the EDS results of points A, B, $\mathrm{C}$, and D marked in Figure 6(b), The chemical compositions (at.\%) are listed in Table 3.

After combining the data in Figures 6(c) and 6(d), along with the data in Table 3 , and then comparing the chemical composition of points $\mathrm{A}, \mathrm{B}$, and $\mathrm{C}$ with the theoretical ratio ranges of intermetallic $\mathrm{TiAl}_{3}, \mathrm{TiAl}_{2}$, and $\mathrm{Ti}_{3} \mathrm{Al}$, it can be determined that the phases of $\mathrm{A}, \mathrm{B}$, and $\mathrm{C}$ were intermetallics $\mathrm{TiAl}_{3}, \mathrm{TiAl}_{2}$, and $\mathrm{Ti}_{3} \mathrm{Al}$, respectively. The $0.9 \mathrm{~mm}$ thick diffusion region mainly consisted of $\mathrm{TiAl}_{3}$ phase, which was formed during the modification reaction between $\mathrm{Al}$ and $\mathrm{Ti}$. The $\mathrm{TiAl}_{2}$ and $\mathrm{Ti}_{3} \mathrm{Al}$ phases were formed in the diffusion front of $\mathrm{Al}$, which consumed $\mathrm{Al}$ and $\mathrm{Ti}$ gradually. The region $\mathrm{D}$ was Ti substrate accorded to the chemical composition.
As shown in Figures 7(a) and 7(b), after the modification reaction at $1173 \mathrm{~K}$ for 5 hours, the thickness of the diffusion region was about $1.1 \mathrm{~mm}$, which increased compared to $1073 \mathrm{~K}$. Also, the region of different shades that appeared in the diffusion front of $\mathrm{Al}$, and the thickness of regions $\mathrm{B}$ and D, all increased compared to $1073 \mathrm{~K}$. Figures $7(\mathrm{c})$ and $7(\mathrm{~d})$ show the EDS results for points $\mathrm{A}, \mathrm{B}, \mathrm{C}, \mathrm{D}$, and $\mathrm{E}$ marked in Figure 7(b). The chemical compositions (at.\%) are listed in Table 4.

After combining data in Figures $7(\mathrm{c})$ and $7(\mathrm{~d})$, along with the data in Table 4, it can be determined that the phases of $\mathrm{A}, \mathrm{B}, \mathrm{C}, \mathrm{D}$, and $\mathrm{E}$ were intermetallics $\mathrm{TiAl}_{3}, \mathrm{TiAl}_{2}$, TiAl, $\mathrm{Ti}_{3} \mathrm{Al}$, and Ti substrate, respectively. The diffusion region still mainly consisted of $\mathrm{TiAl}_{3}$ phase after the modification reaction at $1173 \mathrm{~K}$ for 5 hours. The $\mathrm{TiAl}_{2}$, TiAl, and $\mathrm{Ti}_{3} \mathrm{Al}$ phases were formed in sequence in the diffusion front of $\mathrm{Al}$, which advanced to the Ti substrate. Compared with the modification reaction products which were formed at $1073 \mathrm{~K}$, a new TiAl phase was formed at the interface between $\mathrm{TiAl}_{2}$ layer and $\mathrm{Ti}_{3} \mathrm{Al}$ layer.

From the results above, it is clear that the thickness of the diffusion layer increased with modification reaction temperature, namely, the higher the temperature, the easier the diffusion from $\mathrm{Al}$ to the $\mathrm{Ti}$ substrate for the same reaction time. Furthermore, Ti changed from $\alpha$ to $\beta$ during heating up above $1155 \mathrm{~K}$, and $\mathrm{Al}$ is a relatively fast diffuser in $\beta$-Ti [16].

At test temperature in this paper, $\mathrm{Ti}$ in the substrate also diffused into Al coating. In theory, the higher the temperature, the easier the diffusion from $\mathrm{Ti}$ to the $\mathrm{Al}$ coating as well. Since Ti is a high-melting-point metal, EDS (Figure 2) showed that it was not found that there were a large number of $\mathrm{Ti}$ in residual $\mathrm{Al}$ coating.

There was still sufficient $\mathrm{Al}$ on the surface of the specimen after heating at $973 \mathrm{~K}$ for 5 hours. The obvious layer phenomenon (the interface between $\mathrm{Ti}$ substrate and the $\mathrm{TiAl}_{3}$ phase) did not appear in the diffusion front of Al. The diffusion region only consisted of intermetallic $\mathrm{TiAl}_{3}$, according to the XRD result. In other words, only $3 \mathrm{Al}+\mathrm{Ti}$ $\longrightarrow \mathrm{TiAl}_{3}$ reaction occurred in the diffusion region when there were still sufficient $\mathrm{Al}$ elements on the surface of the specimen.

The $\mathrm{Al}$ coating disappeared and all the $\mathrm{Al}$ elements diffused into the Ti substrate when the modification reaction temperature was raised to $1073 \mathrm{~K}$. The diffusion region still mainly consisted of $\mathrm{TiAl}_{3}$ phase, but the layered distribution region appeared in the diffusion front of $\mathrm{Al}$. The $\mathrm{TiAl}_{2}$ and $\mathrm{Ti}_{3} \mathrm{Al}$ phases formed in sequence in the diffusion front of $\mathrm{Al}$, with decreasing $\mathrm{Al}$ content and increasing $\mathrm{Ti}$ content. In other words, the other $\mathrm{Ti}-\mathrm{Al}$ intermetallic compounds were formed as the reaction proceeded between the $\mathrm{TiAl}_{3}$ phase and Ti substrate, when there was not any $\mathrm{Al}$ on the surface of the specimen.

When the reaction temperature was raised to $1173 \mathrm{~K}$, a new TiAl phase was formed besides the intermetallics $\mathrm{TiAl}_{2}$ and $\mathrm{Ti}_{3} \mathrm{Al}$, which were layered in the diffusion front of $\mathrm{Al}$. According to the result of Sujata et al. [17], $\Delta \mathrm{Gf} \mathrm{TiAl}_{2}<\Delta \mathrm{Gf}$ $\mathrm{TiAl}_{3}<\Delta \mathrm{Gf} \mathrm{Ti}_{3} \mathrm{Al}<\Delta \mathrm{Gf}$ TiAl $<0$ when the temperature range is about $900-1400 \mathrm{~K}$. Intermetallic TiAl was more difficult to be formed than $\mathrm{TiAl}_{2}$ and $\mathrm{Ti}_{3} \mathrm{Al}$ from the 

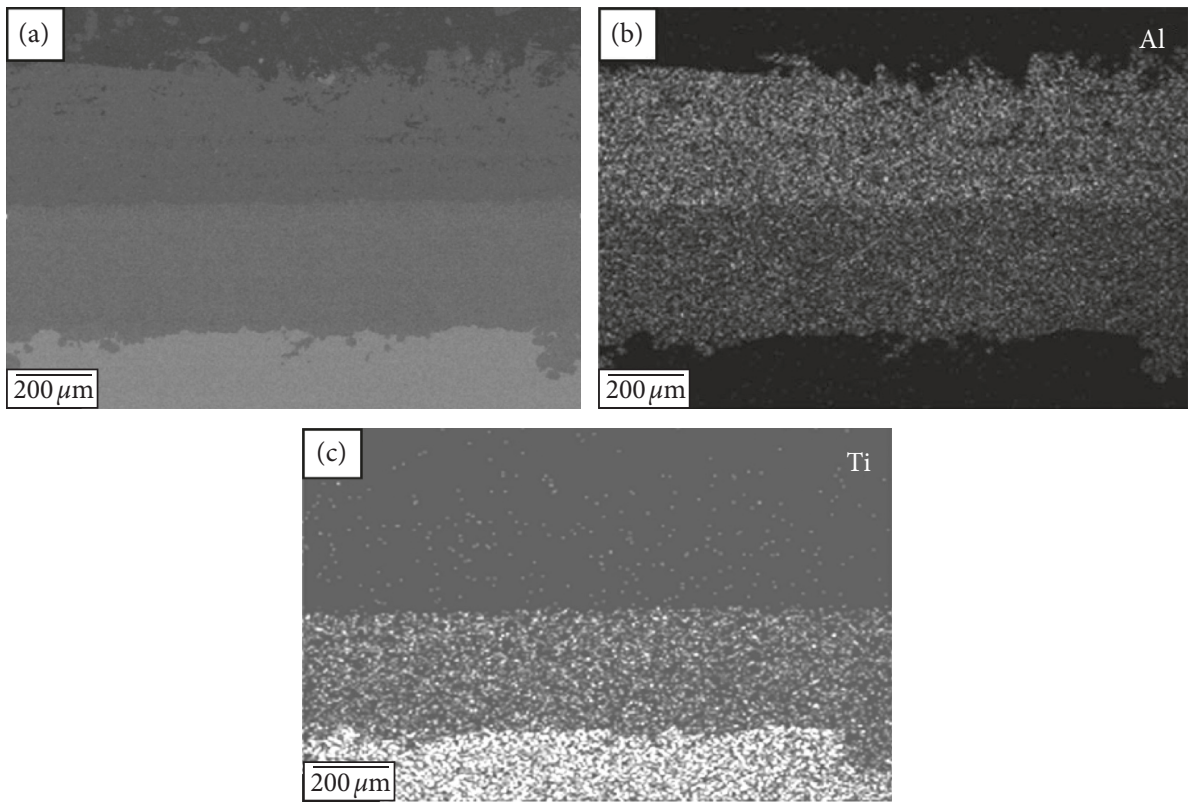

Figure 2: (a) Cross-sectional BSD image of $\mathrm{Al}$ coating after testing for 5 hours at $973 \mathrm{~K}$ and the distributions of (b) Al and (c) Ti.
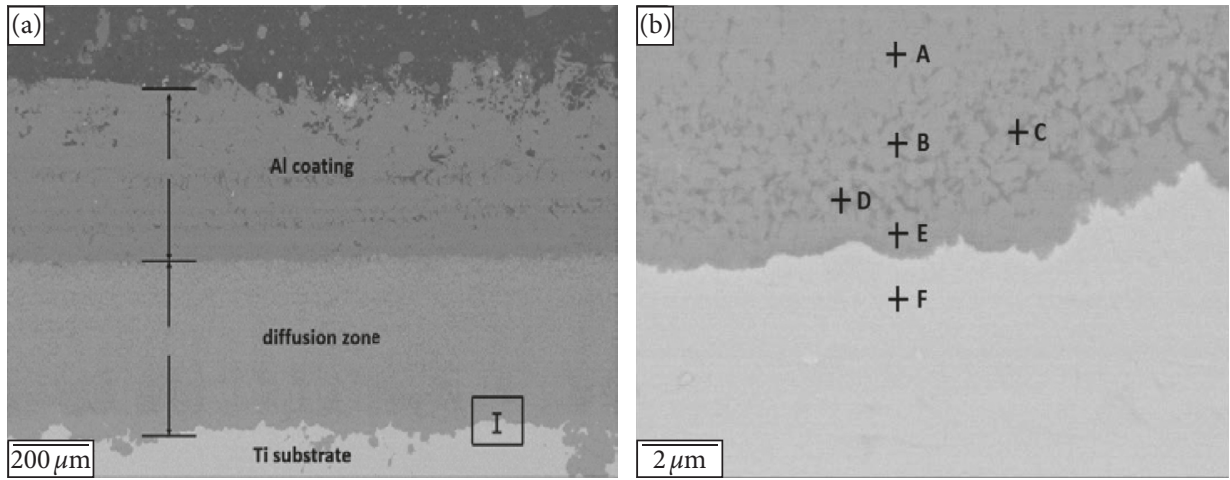

FIgURE 3: (a) Cross-sectional BSD image of $\mathrm{Al}$ coating after testing for 5 hours at $973 \mathrm{~K}$, and (b) the expanded view of region I in Figure 3 (a).

TABle 2: The chemical composition (at.\%) of different points, as marked in Figure 3(b).

\begin{tabular}{lcc}
\hline Points & $\mathrm{Al}$ & $\mathrm{Ti}$ \\
\hline A & 77.61 & 22.39 \\
B & 75.28 & 24.72 \\
C & 78.62 & 21.38 \\
D & 77.79 & 22.21 \\
E & 74.43 & 25.57 \\
F & 0 & 100 \\
\hline
\end{tabular}

thermodynamics, which explains why the TiAl phase formed during the modification reaction at $1173 \mathrm{~K}$, but not at $1073 \mathrm{~K}$.

In addition, the thickness of $\mathrm{TiAl}_{2}$ and $\mathrm{Ti}_{3} \mathrm{Al}$ both increased at $1173 \mathrm{~K}$ compared with at $1073 \mathrm{~K}$. This showed that the increase in the temperature could contribute to further reaction between $\mathrm{TiAl}_{3}$ phase and $\mathrm{Ti}$ substrate.

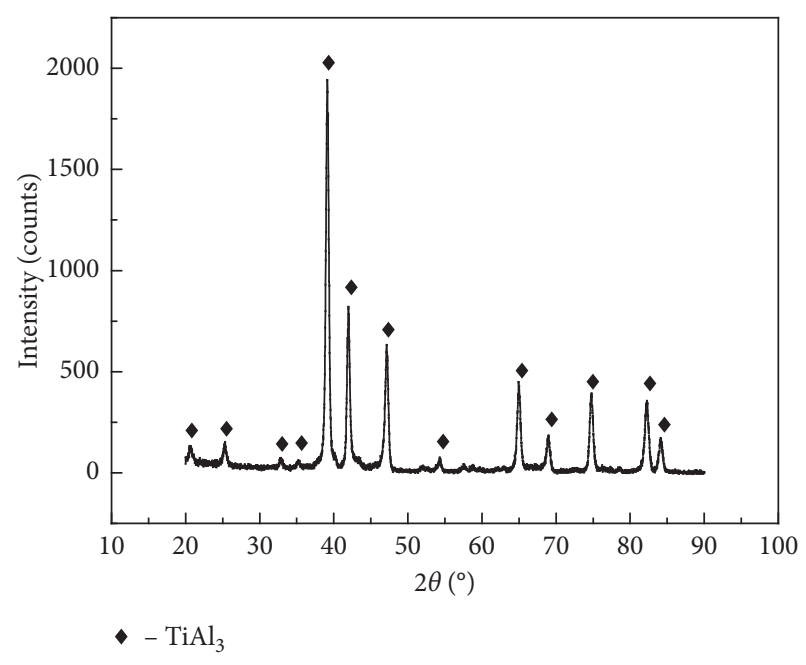

FIGURE 4: XRD spectrum after removal of $500 \mu \mathrm{m}$ thick surface layer. 

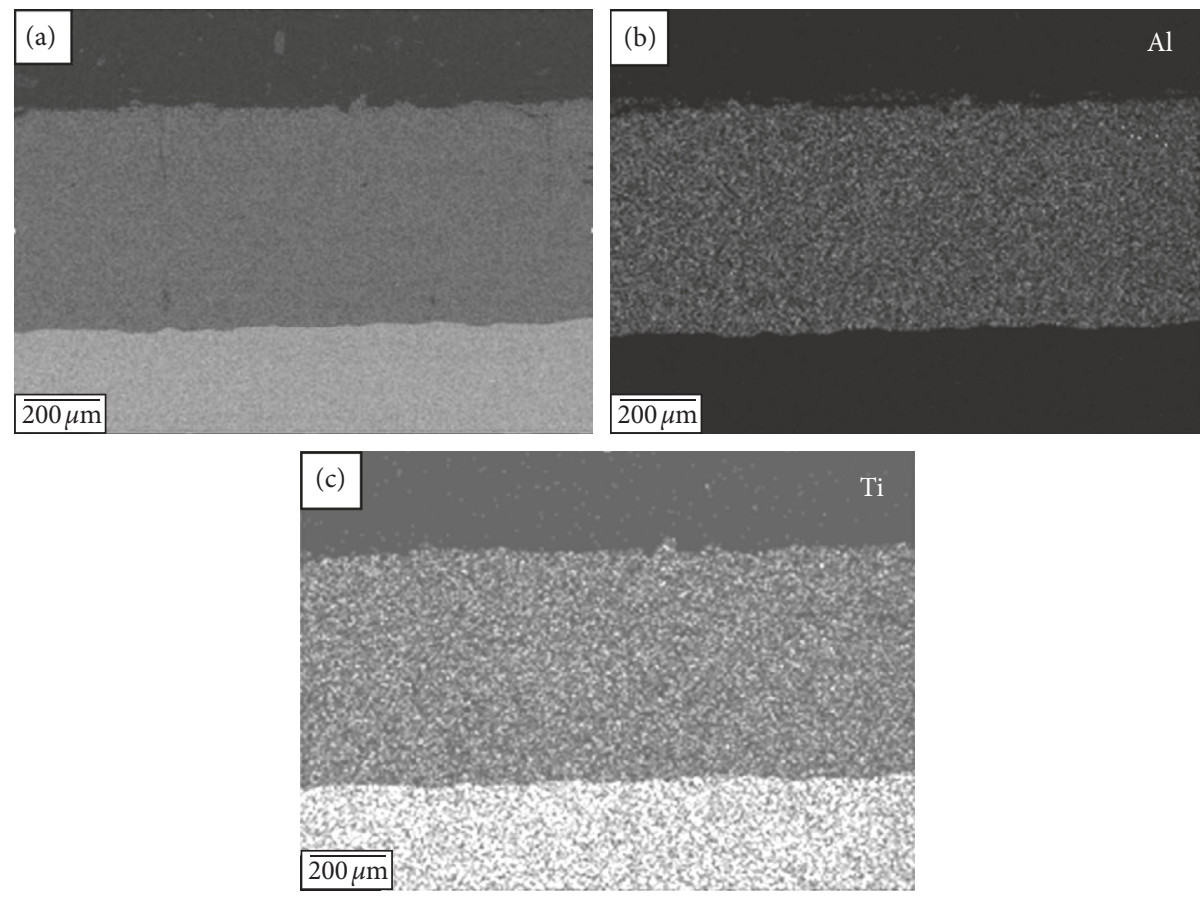

Figure 5: (a) Cross-sectional BSD image of $\mathrm{Al}$ coating after testing for 5 hours at $1073 \mathrm{~K}$ and the distribution of (b) $\mathrm{Al}$ and (c) Ti.
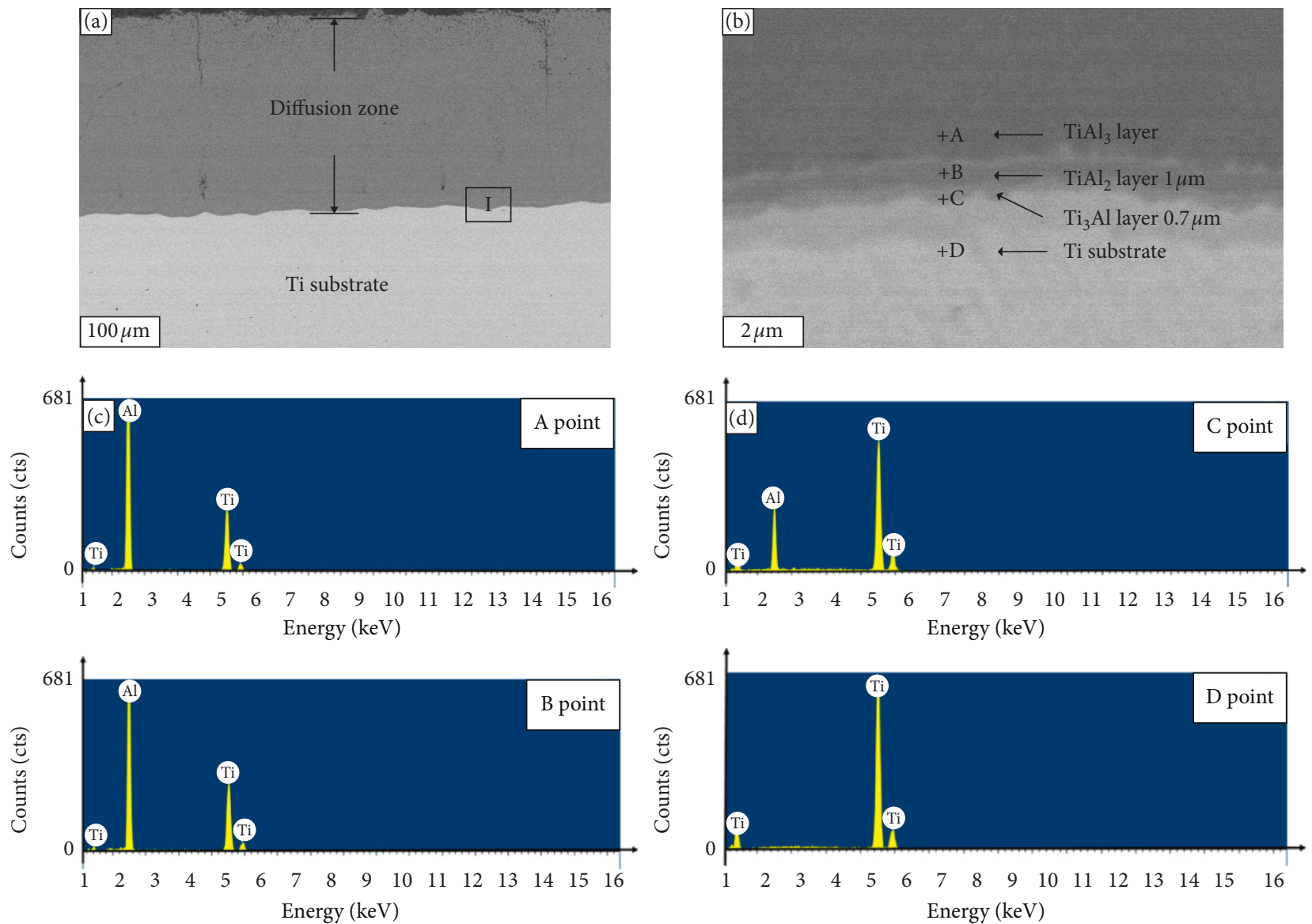

Figure 6: (a) Cross-sectional BSD image of Al coating after testing for 5 hours at $1073 \mathrm{~K}$, (b) the expanded view of region I in Figure 6(a), (c) EDS results of points A and B in Figure 6(b), and (d) EDS results of points C and D marked in Figure 6(b). 
TABLE 3: The chemical composition (at.\%) in different points, as marked in Figure 6(b).

\begin{tabular}{lcc}
\hline Points & Al & Ti \\
\hline A & 73.77 & 26.23 \\
B & 67.49 & 32.51 \\
C & 29.27 & 70.73 \\
D & 0 & 100 \\
\hline
\end{tabular}
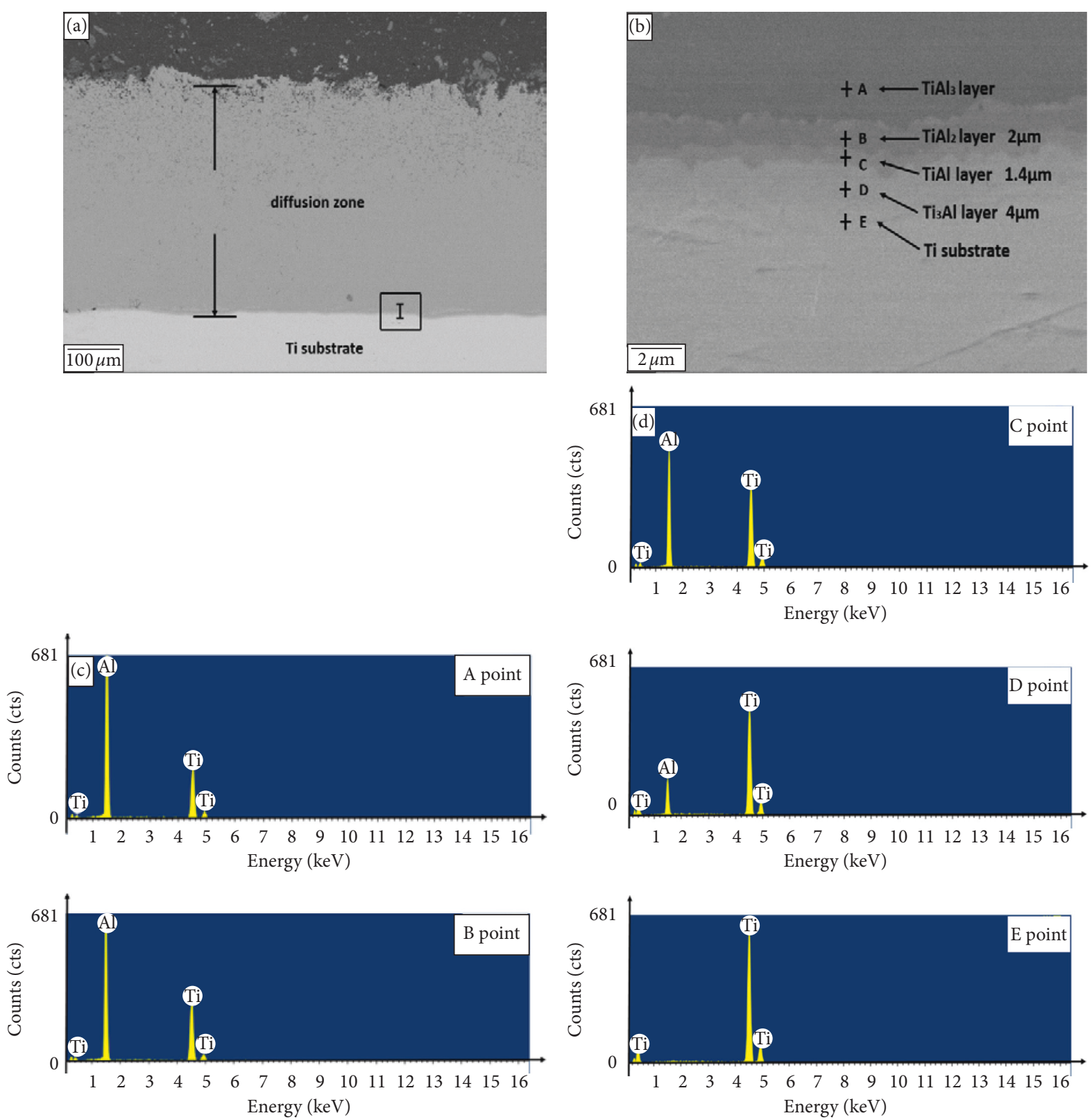

Figure 7: (a) Cross-sectional BSD image of Al coating after testing for 5 hours at $1173 \mathrm{~K}$, (b) the expanded view of region I in Figure 7(a), (c) EDS results of points A and B marked in Figure 7(b), and (d) EDS results of points C, D, and E marked in Figure 7(b).

As shown in Figure 8(a), the microstructure of the diffusion region after modification treatment at $1173 \mathrm{~K}$ for 10 hours was basically identical to it after 5 hours. Figure 8(b) shows that the thickness of $\mathrm{B}, \mathrm{C}$, and $\mathrm{D}$ layers in the diffusion region near the Ti substrate was thicker than that under the reaction condition of $1173 \mathrm{~K} / 5 \mathrm{hr}$. The largest increase in the thickness was layer $\mathrm{B}$, and the smallest one was layer $\mathrm{C}$. The chemical compositions (at.\%) of points A, B, C, D, and E as marked in Figure 8(b) are listed in Table 5.

As seen from the data in Table 5, the products which were formed after modification treatment at $1173 \mathrm{~K}$ for 10 hours, and their distributions, were not significantly 
TABLe 4: The chemical composition (at.\%) in different points, as marked in Figure 7(b).

\begin{tabular}{lcc}
\hline Points & Al & Ti \\
\hline A & 74.08 & 25.92 \\
B & 65.12 & 34.88 \\
C & 52.22 & 47.78 \\
D & 22.08 & 77.92 \\
E & 0 & 100 \\
\hline
\end{tabular}
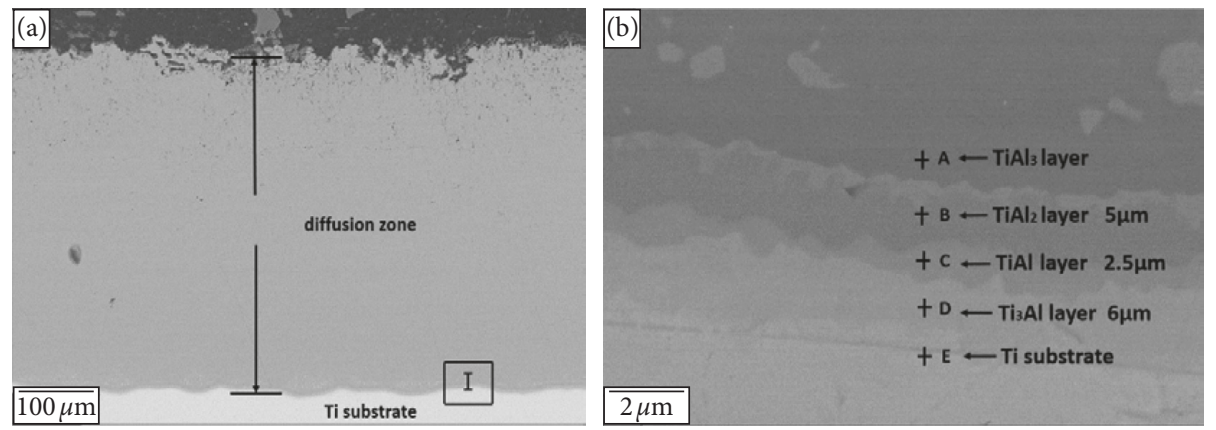

Figure 8: (a) Cross-sectional BSD image of Al coating after testing for 10 hours at $1173 \mathrm{~K}$ and (b) the expanded view of region I in Figure 8 (a).

TABLE 5: The chemical composition (at.\%) in different points, as marked in Figure 8(b).

\begin{tabular}{lcc}
\hline Points & Al & Ti \\
\hline A & 74.08 & 25.92 \\
B & 65.37 & 34.63 \\
C & 48.06 & 51.94 \\
D & 26.42 & 73.58 \\
E & 0 & 100 \\
\hline
\end{tabular}

changed compared with that under the reaction condition of $1173 \mathrm{~K}$ for $5 \mathrm{~h}$. The diffusion region still mainly consisted of $\mathrm{TiAl}_{3}$ phase and intermetallics $\mathrm{TiAl}_{2}, \mathrm{TiAl}$, and $\mathrm{Ti}_{3} \mathrm{Al}$ formed in sequence in the diffusion front of $\mathrm{Al}$.

As shown in Figure 9(a), the layered structure was more obvious in the diffusion front of $\mathrm{Al}$ after modification treatment at $1173 \mathrm{~K}$ for 20 hours. In addition, it can be seen in Figure 9(a) that the thickness of B and D layers increased compared with that under the reaction condition of $1173 \mathrm{~K}$ for 10 hours. The $\mathrm{C}$ layer had less change in the thickness. The chemical compositions (at.\%) of points A, B, C, D, and E as marked in Figure 9(b) are listed in Table 6.

As can be seen from the data in Table 6, the products which were formed after the modification treatment of the specimen at $1173 \mathrm{~K}$ for 20 hours, and their distributions, were all the same with that under the reaction condition of $1173 \mathrm{~K}$ for 5 hours and $1173 \mathrm{~K}$ for 10 hours.

As shown in Figure 9(c), the layered structure in the diffusion front of Al was comprised of different kinds of Ti$\mathrm{Al}$ intermetallic. It could be revealed that the element ratio of titanium to aluminum in $\mathrm{TiAl}_{3}$ and $\mathrm{TiAl}_{2}$ was a fixed value, but for $\mathrm{TiAl}$ and $\mathrm{Ti}_{3} \mathrm{Al}$, it was within a certain range.
The products formed after the modification treatment of the specimens at $1173 \mathrm{~K}$ for 10 and 20 hours, and their distributions, were the same as that under the reaction condition of $1173 \mathrm{~K}$ for 5 hours. The diffusion region mainly consisted of intermetallic $\mathrm{TiAl}_{3}$, and intermetallics $\mathrm{TiAl}_{2}$, $\mathrm{TiAl}$, and $\mathrm{Ti}_{3} \mathrm{Al}$ were formed in sequence in the diffusion front of $\mathrm{Al}$, with decreasing $\mathrm{Al}$ content and increasing $\mathrm{Ti}$ content.

As can be seen from the data in Table 7, the thickness of $\mathrm{TiAl}_{2}$, TiAl, and $\mathrm{Ti}_{3} \mathrm{Al}$ layers were all increased as the reaction time was prolonged. This was because a concentration gradient of Ti was still present between $\mathrm{TiAl}_{3}$ phase and $\mathrm{Ti}$ substrate. The Ti element in Ti substrate continuously diffused into $\mathrm{TiAl}_{3}$ layer and reacted with it under the concentration gradient driving forces, and then intermetallics $\mathrm{TiAl}_{2}$, TiAl, and $\mathrm{Ti}_{3} \mathrm{Al}$ were formed. It is also apparent from Table 7 that the increased thickness of $\mathrm{TiAl}_{2}$ layer $>$ the increased thickness of $\mathrm{Ti}_{3} \mathrm{Al}$ layer $>$ the increased thickness of TiAl layer. This was because, as mentioned above, $\Delta \mathrm{Gf}$ $\mathrm{TiAl}_{2}<\Delta \mathrm{Gf} \mathrm{TiAl}_{3}<\Delta \mathrm{Gf} \mathrm{Ti}_{3} \mathrm{Al}<\Delta \mathrm{Gf} \mathrm{TiAl}<0$ when the temperature range is about $900-1400 \mathrm{~K}$. Therefore, the formation amount of $\mathrm{TiAl}_{2}$ phase $>$ the formation amount of $\mathrm{Ti}_{3} \mathrm{Al}$ phase $>$ the formation amount of TiAl phase. The growth of $\mathrm{TiAl}_{2}$ phase and TiAl phase was in a competitive relationship, and the growth speed of $\mathrm{TiAl}_{2}$ was 1.4 times the growth speed of TiAl [18]. This also made that the increase in the thickness of $\mathrm{TiAl}_{2}$ layer larger than that of $\mathrm{TiAl}$ layer as the reaction proceeded.

In order to test the high temperature oxidation resistance of Ti-Al intermetallics which were formed during the modification reaction, $100 \mu \mathrm{m}$ thick $\mathrm{Al}_{2} \mathrm{O}_{3}$ surface layer that occurred after the modification reaction at $1173 \mathrm{~K}$ for 20 hours was removed by waterproof abrasive paper to expose the $\mathrm{TiAl}_{3}$ layer completely. Then, oxidation resistance of the $\mathrm{Al} / \mathrm{Ti}$ specimen after treatment and the pure $\mathrm{Ti}$ without 

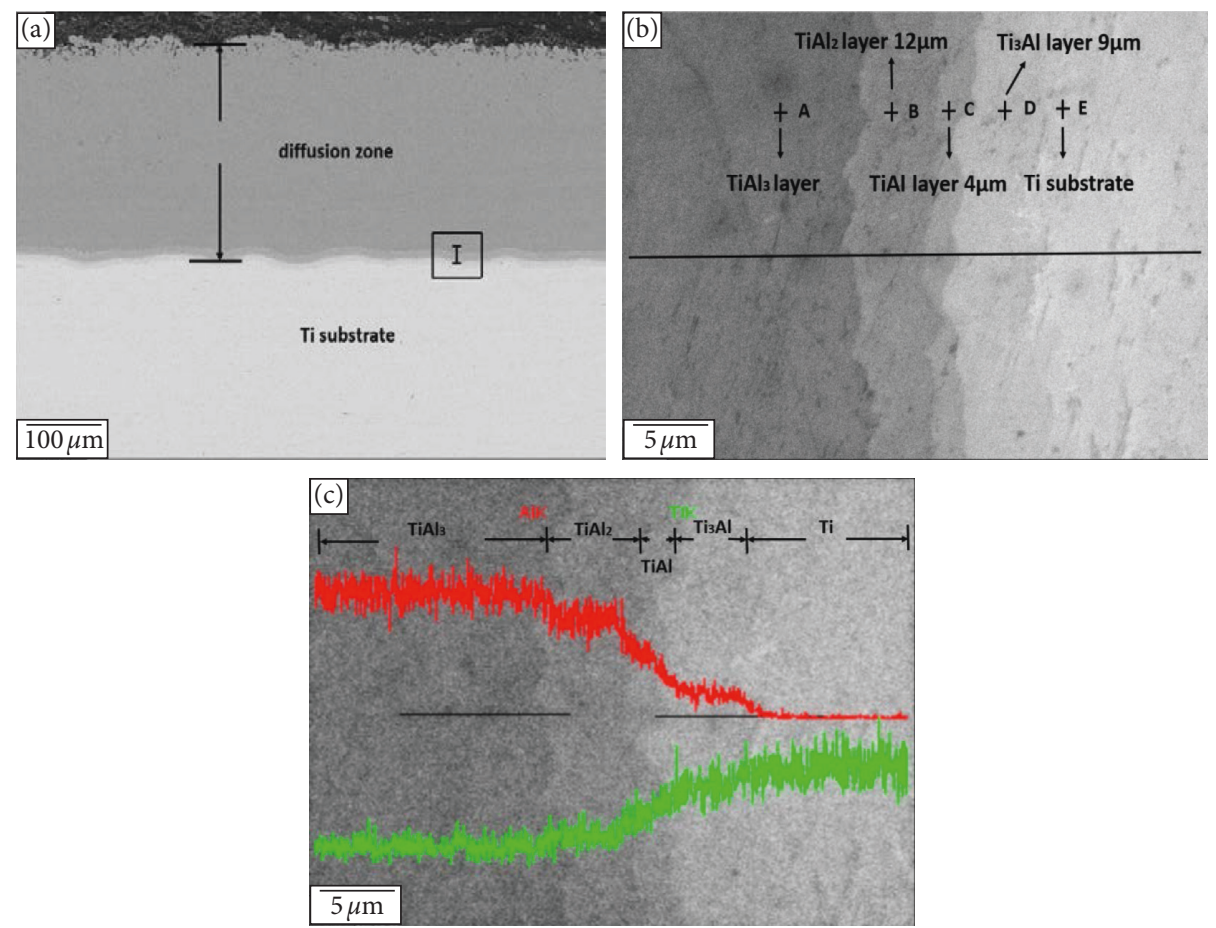

FIgURE 9: (a) Cross-sectional BSD image of Al coating after testing for 20 hours at $1173 \mathrm{~K}$, (b) the expanded view of region I in Figure 9(a), and (c) concentration profiles of $\mathrm{Al}$, Ti elements in Figure 9(b).

TABle 6: The chemical composition (at.\%) in different points, as marked in Figure 9(b).

\begin{tabular}{lcc}
\hline Points & $\mathrm{Al}$ & $\mathrm{Ti}$ \\
\hline $\mathrm{A}$ & 74.74 & 25.26 \\
$\mathrm{~B}$ & 65.65 & 34.35 \\
C & 50.44 & 49.56 \\
$\mathrm{D}$ & 22.04 & 77.96 \\
E & 0 & 100 \\
\hline
\end{tabular}

TABLe 7: Thickness $(\mu \mathrm{m})$ of different Ti-Al Intermetallics layers with $1173 \mathrm{~K} / 5 \mathrm{~h}, 1173 \mathrm{~K} / 10 \mathrm{~h}$, and $1173 \mathrm{~K} / 20 \mathrm{~h}$.

\begin{tabular}{lccc}
\hline Ti-Al intermetallics & $1173 \mathrm{~K} / 5 \mathrm{~h}$ & $1173 \mathrm{~K} / 10 \mathrm{~h}$ & $1173 \mathrm{~K} / 20 \mathrm{~h}$ \\
\hline $\mathrm{TiAl}_{2}$ & 2 & 5 & 12 \\
$\mathrm{TiAl}$ & 1.4 & 2.5 & 4 \\
$\mathrm{Ti}_{3} \mathrm{Al}$ & 4 & 6 & 9 \\
\hline
\end{tabular}

coating were performed at $1073 \mathrm{~K}$ for 100 hours under air atmosphere.

It could be seen from the oxidizing dynamic curves in Figure 10 that the curve for the pure Ti without coating is nearly straight. This was in a high-temperature environment, so it was easy for $\mathrm{Ti}$ to be oxidized by molecular oxygen to produce $\mathrm{TiO}_{2}$, which was easy to break. The $\mathrm{TiO}_{2}$, which had a rutile structure, peeled off from the surface of the pure Ti specimen and the exposed Ti substrate to be oxidized again.

The oxygen weight gain of the $\mathrm{Al} / \mathrm{Ti}$ specimen (after modification treatment and removal of the $\mathrm{Al}_{2} \mathrm{O}_{3}$ film) in the later stage of the oxidation exhibited a reduction as compared to the beginning of the oxidation. This was because intermetallics $\mathrm{TiAl}_{3}, \mathrm{TiAl}_{2}$, and others, which were rich in $\mathrm{Al}$,

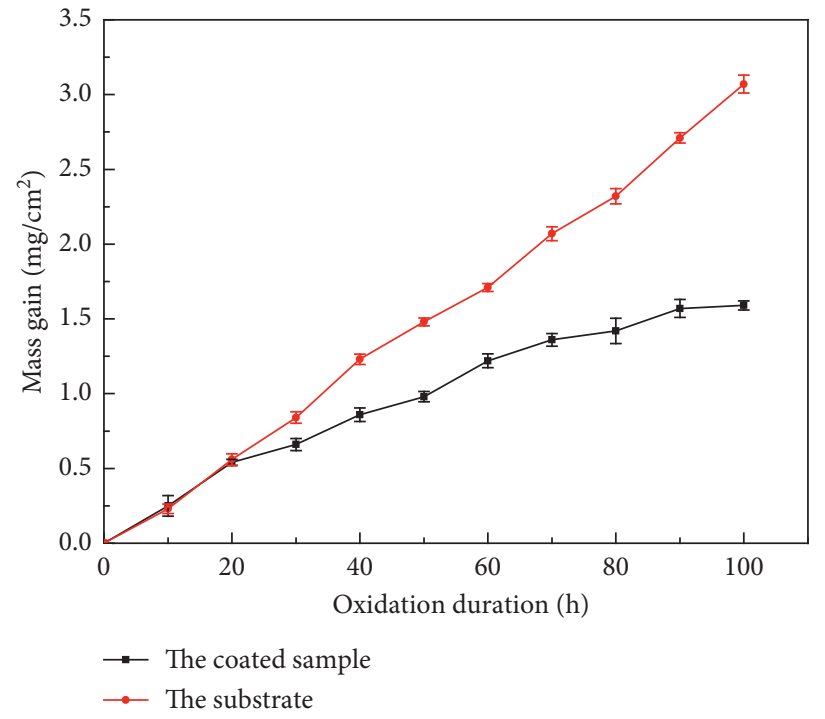

FIgURE 10: Oxidation kinetics curves of Ti alloy with and without coating at $1073 \mathrm{~K}$ for $100 \mathrm{~h}$ (10 cycles).

formed in the process of modification reaction between the $\mathrm{Al}$ coating and $\mathrm{Ti}$ substrate. The $\mathrm{Al}_{2} \mathrm{O}_{3}$ was formed by the reaction between $\mathrm{Al}$-rich $\mathrm{TiAl}_{3}$ phase and the oxygen in air at the beginning of the oxidation. The surface of the specimen was covered with $\mathrm{Al}_{2} \mathrm{O}_{3}$ film, which increased constantly. Furthermore, the oxidation of the specimen was sufficiently suppressed. But a little amount of the $\mathrm{Al}_{2} \mathrm{O}_{3}$ film peeled off from the surface of the specimen with the increase in the high temperature oxidation time, and the exposed $\mathrm{TiAl}_{3}$ 
phase would be oxidized again. The weight of the specimen also increased during the later stage of the oxidation but with smaller increasing amount.

The total weight gain of noncoated $\mathrm{Ti}$ and coated $\mathrm{Al} / \mathrm{Ti}$ specimen was $3.1 \mathrm{mg}$ and $1.6 \mathrm{mg}$, respectively, after oxidation for 100 hours as it is shown in Figure 10. The total weight gain of noncoated $\mathrm{Ti}$ was almost twice than the coated $\mathrm{Al} / \mathrm{Ti}$ specimens.

The Al/Ti specimens after modification treatment had a better high temperature oxidation resistance than the pure Ti without protection coating.

\section{Conclusions}

(1) After heating at $973 \mathrm{~K}$ for 5 hours, there was still sufficient $\mathrm{Al}$ on the surface of the specimen, and only intermetallic $\mathrm{TiAl}_{3}$ formed in the diffusion region.

(2) After heating at $1073 \mathrm{~K}$ for 5 hours, all of the $\mathrm{Al}$ diffused into the $\mathrm{Ti}$ substrate, and intermetallics $\mathrm{TiAl}_{2}$ and $\mathrm{Ti}_{3} \mathrm{Al}$ also formed in the diffusion front of $\mathrm{Al}$, in addition to $\mathrm{TiAl}_{3}$.

(3) After heating at $1173 \mathrm{~K}$ for 5 hours, a new intermetallic TiAl phase was formed at the interface of $\mathrm{TiAl}_{2}$ and $\mathrm{Ti}_{3} \mathrm{Al}$, in addition to the intermetallics $\mathrm{TiAl}_{2}$ and $\mathrm{Ti}_{3} \mathrm{Al}$ in the zone of the diffusion reaction.

(4) As the modification reaction time was prolonged at $1173 \mathrm{~K}$, the formation of intermetallics $\mathrm{TiAl}_{2}, \mathrm{TiAl}$, and $\mathrm{Ti}_{3} \mathrm{Al}$ all increased, and among them, the formation amount of $\mathrm{TiAl}_{2}$ phase > the formation amount of $\mathrm{Ti}_{3} \mathrm{Al}$ phase $>$ the formation amount of TiAl phase.

(5) The $\mathrm{Al} / \mathrm{Ti}$ specimens after modification treatment had better high temperature oxidation resistance than the pure $\mathrm{Ti}$ without protection coating.

\section{Data Availability}

The data used to support the findings of this study are available from the corresponding author upon request.

\section{Conflicts of Interest}

The authors declare that there are no conflicts of interest regarding the publication of this paper.

\section{Acknowledgments}

This work was financially supported by the Natural Science Foundation of Liaoning Province (No. 201602553) Chinese National Natural Science Foundation (No. 51301112).

\section{References}

[1] H. Riedl, C. M. Koller, F. Munnik et al., "Influence of oxygen impurities on growth morphology, structure and mechanical properties of Ti-Al-N thin films," Thin Solid Films, vol. 603, pp. 39-49, 2016.

[2] H. Z. Cui, L. Ma, L. L. Cao, F. L. Teng, and N. Cui, "Effect of $\mathrm{NiAl}$ content on phases and microstructures of TiC-TiB2-
NiAl composites fabricated by reaction synthesis," Transactions of Nonferrous Metals Society of China, vol. 24, no. 2, pp. 346-353, 2014.

[3] H. Sina, K. B. Surreddi, and S. Iyengar, "Phase evolution during the reactive sintering of ternary $\mathrm{Al}-\mathrm{Ni}$-Ti powder compacts," Journal of Alloys and Compounds, vol. 661, pp. 294-305, 2016.

[4] M. L. Vera, Á. Colaccio, M. R. Rosenberger, C. E. Schvezov, and A. E. Ares, "Influence of the electrolyte concentration on the smooth $\mathrm{TiO}_{2}$ anodic coatings on Ti-6Al-4V," Coatings, vol. 7, no. 3, p. 39, 2017.

[5] C. O’Sullivan, P. O’Hare, G. Byrne, L. O’Neill, K. B. Ryan, and A. M. Crean, "A modified surface on titanium deposited by a blasting process," Coatings, vol. 1, no. 1, pp. 53-71, 2011.

[6] Q. Jia, D. Li, S. Li, Z. Zhang, and N. Zhang, "High-temperature oxidation resistance of $\mathrm{NiAl}$ intermetallic formed in situ by thermal spraying," Coatings, vol. 8, no. 8, p. 292, 2018.

[7] Y. M. Xiong, S. L. Zhu, and F. H. Wang, "The oxidation behavior of TiAlNb intermetallics with coatings at $800^{\circ} \mathrm{C}$," Surface and Coatings Technology, vol. 197, no. 2-3, pp. 322326, 2005.

[8] M. M. Zhang, M. L. Shen, L. Xin, X. Y. Ding, S. L. Zhu, and F. H. Wang, "High vacuum arc ion plating TiAl coatings for protecting titanium alloy against oxidation at medium high temperatures," Corrosion Science, vol. 112, pp. 36-43, 2016.

[9] C. Cheng, X. M. Feng, and Y. F. Shen, "Oxidation behavior of a high Si content Al-Si composite coating fabricated on Ti$6 \mathrm{Al}-4 \mathrm{~V}$ substrate by mechanical alloying method," Journal of Alloys and Compounds, vol. 701, pp. 27-36, 2017.

[10] I. N. Maliutina, H. Mohand, J. Sijobert, P. Bertrand, D. V. Lazurenko, and I. A. Bataev, "Structure and oxidation behavior of $\gamma$-TiAl coating produced by laser cladding on titanium alloy," Surface and Coatings Technology, vol. 319, pp. 136-144, 2017.

[11] M. Tavoosi and S. Arjmand, "In situ formation of $\mathrm{Al} / \mathrm{Al}_{3} \mathrm{Ti}$ composite coating on pure Ti surface by TIG surfacing process," Surfaces and Interfaces, vol. 8, pp. 1-7, 2017.

[12] J. J. Dai, F. Y. Zhang, A. M. Wang, H. J. Yu, and C. Z. Chen, "Microstructure and properties of Ti-Al coating and $\mathrm{Ti}-\mathrm{Al}-\mathrm{Si}$ system coatings on Ti-6Al-4V fabricated by laser surface alloying," Surface and Coatings Technology, vol. 309, pp. 805-813, 2017.

[13] J. Q. Wang, L. Y. Kong, T. F. Li, and T. Y. Xiong, "A novel $\mathrm{TiAl}_{3} / \mathrm{Al}_{2} \mathrm{O}_{3}$ composite coating on $\gamma$-TiAl alloy and evaluating the oxidation performance," Applied Surface Science, vol. 361, pp. 90-94, 2016.

[14] Y. Sun, Z. P. Wan, L. X. Hu, B. H. Wu, and T. Q. Deng, "Characterization on solid phase diffusion reaction behavior and diffusion reaction kinetic of Ti/Al," Rare Metal Materials and Engineering, vol. 46, no. 8, pp. 2080-2086, 2017.

[15] J. Q. Wang, L. Y. Kong, J. Wu, T. F. Li, and T. Y. Xiong, "Microstructure evolution and oxidation resistance of siliconaluminizing coating on $\gamma$-TiAl alloy," Applied Surface Science, vol. 356, pp. 827-836, 2015.

[16] Y. Mishin and C. Herzig, "Diffusion in the Ti-Al system," Acta Materialia, vol. 48, no. 3, pp. 589-623, 2000.

[17] M. Sujata, S. Bhargava, and S. Sangal, "On the formation of $\mathrm{TiAl}_{3}$ during reaction between solid Ti and liquid $\mathrm{Al}$," Journal of Materials Science Letters, vol. 16, no. 13, pp. 1175-1178, 1997.

[18] R. Martin, S. L. Kampe, J. S. Marte, and T. P. Pete, "Microstructure/processing relationships in reactionsynthesized titanium aluminide intermetallic matrix composites," Metallurgical and Materials Transactions A, vol. 33, no. 8, pp. 2747-2753, 2002. 


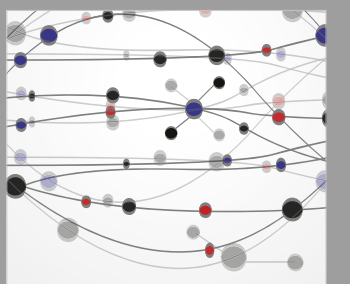

The Scientific World Journal
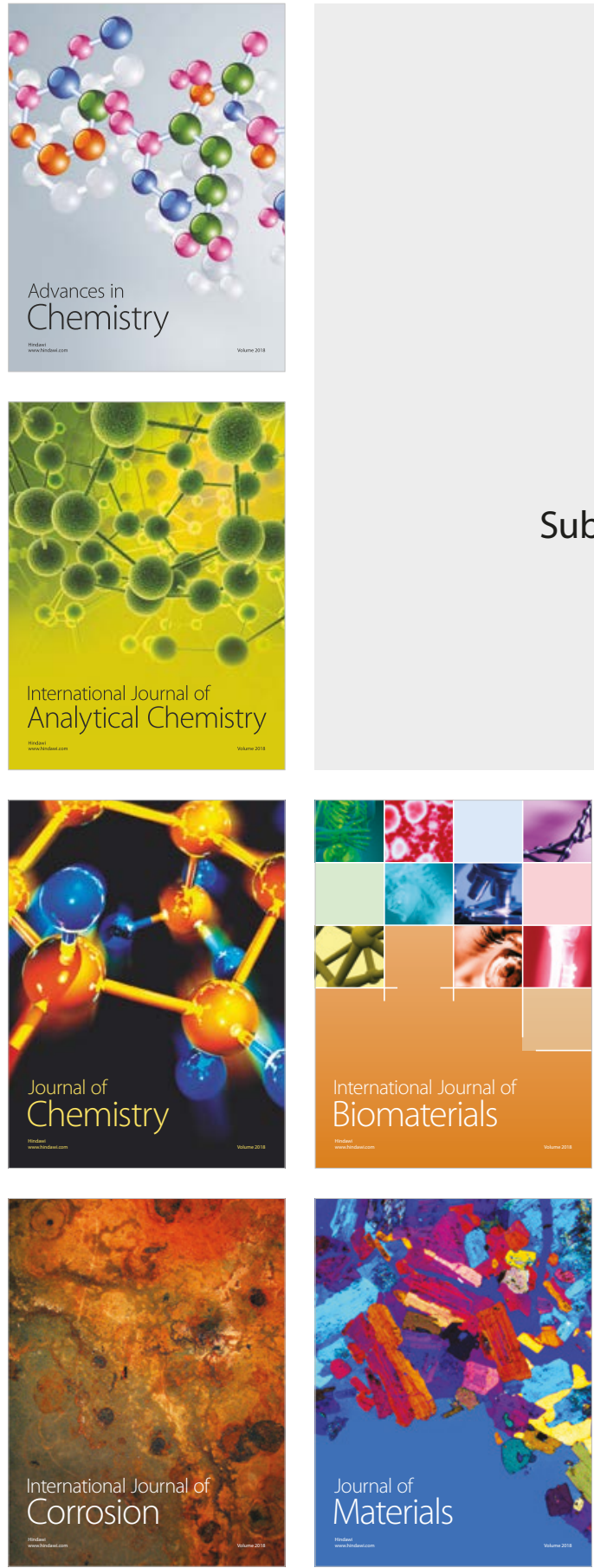

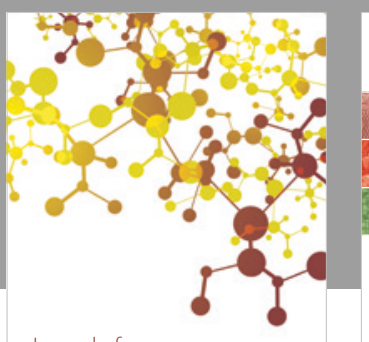

Journal of

Applied Chemistry
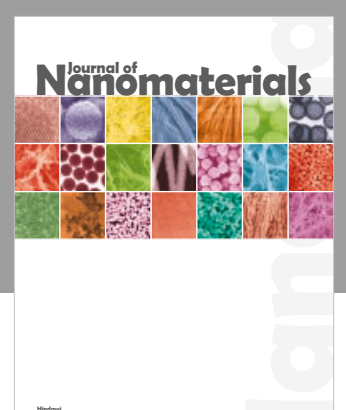

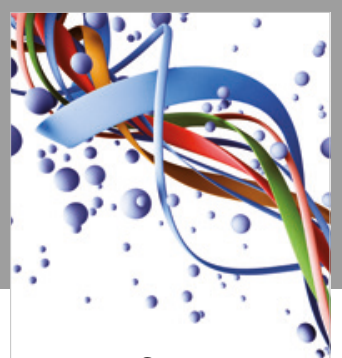

Scientifica

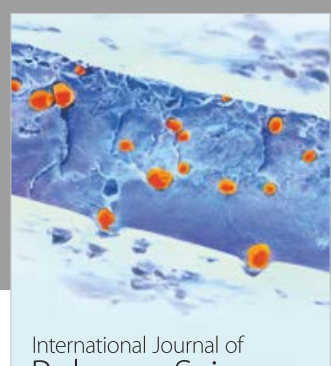

Polymer Science

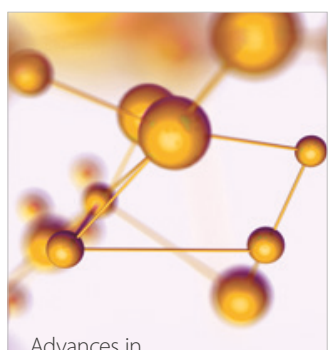

Physical Chemistry
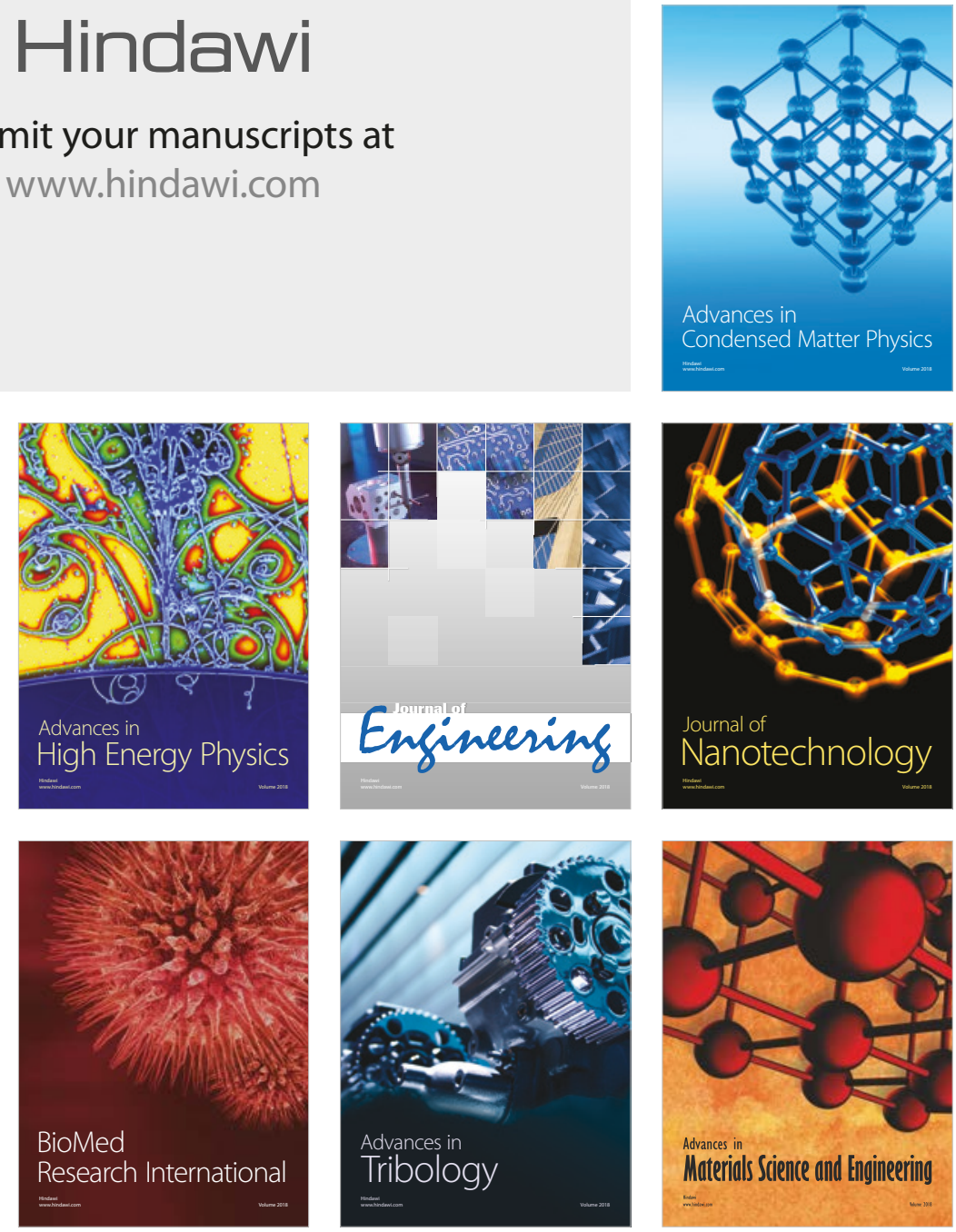